\title{
Effect of High-Flow Nasal Oxygen Therapy on Tracheobronchial Mucosa in COVID-19 Cases
}

\author{
COVID-19 Olgularında Yüksek Akımlı Nazal Oksijen Tedavisinin \\ Trakeobronşiyal Mukozaya Etkisi
}

Melahat Uzel Şener', Semih Aydemir², Ayperi Ozturk'

\begin{abstract}
In the ongoing COVID-19 pandemic, several patients have experienced respiratory failure, for which highflow nasal oxygen therapy (HFNO) is a frequently preferred treatment modality. In the present study, three COVID-19 patients being followed up with HFNO in the intensive care unit underwent fiberoptic bronchoscopy, and a burned/wounded mucosa with widespread hyperemia, hyperpigmentation and mucosal damage throughout the entire tracheobronchial system mucosa was detected in all cases, the longterm effects of which are unknown. Herein, we aim to draw attention to the possible development of mucosal damage after HFNO, which should be kept in mind during the provision of ventilation support to COVID-19 patients.
\end{abstract}

Key words: High-Flow Oxygen, COVID-19, Bronchoscopy, bronchial mucosa.

\section{Özet}

COVID-19 pandemisinde birçok hastada solunum yetmezliği gelişir ve yüksek akımlı nazal oksijen tedavisi (HFNO) sıklıkla tercih edilen bir tedavi yöntemidir. Yoğun bakım ünitesinde HFNO ile izlenen üç COVID-19 hastasına fiberoptik bronkoskopi uyguladık. Her iki hastada da, trakeobronşiyal sistem mukozasının tamamında yaygın hiperemi, hiperpigmentasyon ve mukozal hasar ile birlikte yanmış/hasarlı bir mukoza tespit edildi. Uzun vadeli etkileri bilinmemektedir. Bu yazıda HFNO sonrası gelişen mukozal hasara dikkat çekmek istiyoruz. COVID-19 hastalarında ventilasyon desteğine karar verirken bu etkilerin dikkate alınması uygun olacaktır.

Anahtar Sözcükler: Yüksek-akım oksijen, COVID-19, bronkoskopi, bronşiyal mukoza.
'Department of Chest Disease, University of Health Sciences, Ankara Atatürk Chest Diseases and Thoracic Surgery Training and Research Hospital, Ankara, Turkey

${ }^{2}$ Department of Intensive Care Unit, University of Health Sciences, Ankara Atatürk Chest Diseases and Thoracic Surgery Training and Research Hospital, Ankara, Turkey

\author{
'Sağlık Bilimleri Üniversitesi, Ankara Atatürk Göğüs Has- \\ talıkları ve Göğüs Cerrahisi Eğitim ve Araştırma Hastanesi, \\ Göğüs Hastalıkları Kliniği, Ankara \\ ${ }^{2}$ Sağlık Bilimleri Üniversitesi, Ankara Atatürk Göğüs Has- \\ talıkları ve Göğüs Cerrahisi Eğitim ve Araşıırma Has- \\ tanesi,Yoğun Bakım Ünitesi, Ankara
}

Submitted (Başvuru tarihi): 14.02.2021 Accepted (Kabul tarihi): 14.05.2021

Correspondence (iletişim): Melahat Uzel Şener, Department of Chest Disease, University of Health Sciences, Ankara Atatürk Chest Diseases and Thoracic Surgery Training and Research Hospital, Ankara, Turkey

e-mail: melahatuzeldr@yahoo.com.tr 
Severe Acute Respiratory Syndrome Coronavirus-2 (SARSCOV2) disease, which first emerged in China and spread rapidly around the world, is mostly mild/asymptomatic, although critical symptoms develop in $5-15 \%$ of cases (1) This minority of critical patients has placed an unexpected burden on the healthcare systems of every country, and has led to a significant increase in the requirement for intensive care. Acute hypoxemic respiratory failure generally develops in severe cases of COVID-19, often requiring advanced oxygen therapy procedures such as HFNO, and non-invasive/invasive mechanical ventilation, among which HFNO, which can provide high fractional oxygen concentrations, has become the first-choice approach for the avoidance of invasive procedures (2). It has been stated that with the HFNO method, the need for invasive mechanical ventilation and the risk of ventilatorassociated pneumonia is reduced, lessening the burden on the healthcare system (3).

As HFNO is thought to cause the spread of infective particles in ambient air, it should be preferred in cases refractory to conventional oxygen therapy (COT).

Therapeutic fiberoptic bronchoscopy (FOB) was performed in three patients who were intubated due to clinical deterioration, and who developed atelectasis and hypoxia after being followed up with HFNO in the intensive care unit of our hospital. We present these cases to draw attention to the mucosal findings that may develop after HFNO. Literature contains no reports on similar oxygen toxicities in patients undergoing HFNO.

\section{CASE}

Case-1: A 75-year-old female patient was started on HFNO treatment after suffering hypoxic respiratory failure 3 days after being diagnosed with COVID-19. The patient was followed with HFNO treatment for 6 days via inspired oxygen fraction $\left(\mathrm{FiO}_{2}\right): 100 \%$ and flow rate $40 \mathrm{~L} /$ min. Left total atelectasis was detected on a chest $\mathrm{X}$-ray investigating the increased secretions and dyspnea progression, thereupon, FOB was performed on the 11th day following the diagnosis of COVID-19 pneumonia. Mucosal burn, accompanied by widespread hyperemia, hyperpigmentation and mucosal damage from the distal of the vocal cords to the subsegments, and throughout the entire tracheobronchial system, was observed. None of the mucosa was undamaged (Figure 1). The left lung was ventilated again by bronchoscopy for the aspiration of the secretions that were obstructing the left main bronchus.
Case-2: An 85-year-old male patient was started on HFNO therapy due to hypoxic respiratory failure 2 days after being diagnosed with COVID-19 pneumonia. The patient was followed up with $\mathrm{HFNO}$, reducing $\mathrm{FiO}_{2}$ gradvally from $100 \%$ to $60 \%$ over 8 days, but the patient needed to be intubated on the 10th day of follow-up due to deepening hypoxia, and FOB was performed simultaneously with the intubation to collect culture specimens and to clear the secretions. Mucosal damage accompanied by diffuse mucosal hyperemia, hyperpigmentation and an atrophic appearance were identified in the area extending from the lower end of the endotracheal tube throughout the entire trachea, the main bronchi and the whole subsegment (Figure 2).

Case-3: A 41-year-old male patient being treated for COVID-19 pneumonia was started on HFNO treatment on the fourth day due to respiratory failure. After being followed with $100 \% \mathrm{FiO}_{2}$ and $40 \mathrm{lt} / \mathrm{min}$ flow for 5 days, the patient was intubated due to deepening hypoxia. In the FOB performed for secretion cleaning after intubation, mucosal damage accompanied by "diffuse mucosal hyperemia, hyperpigmentation, and atrophic appearance" could be observed beginning from the lower end of the endotracheal tube along the entire segmental bronchial mucosa (Figure 3). It was observed one month after the procedure that the mucosa become more atrophic and erosive after $\mathrm{FOB}$ was performed for a second time due to post-intubation tracheal stenosis.

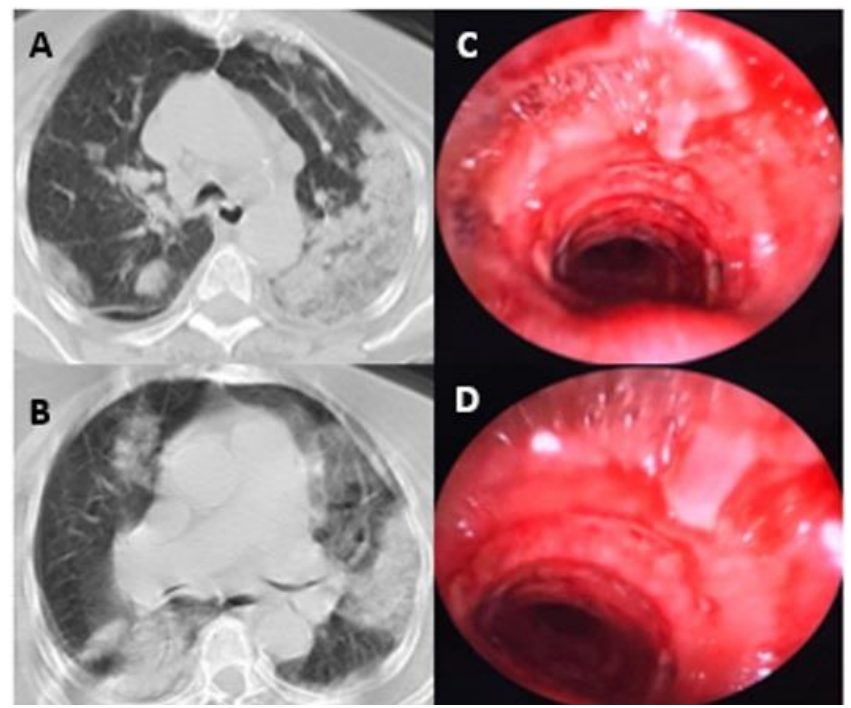

Figure 1: Bilateral consolidation, ground-glass opacity $(a, b)$, wounded mucosa, trachea $(c, d)$ 


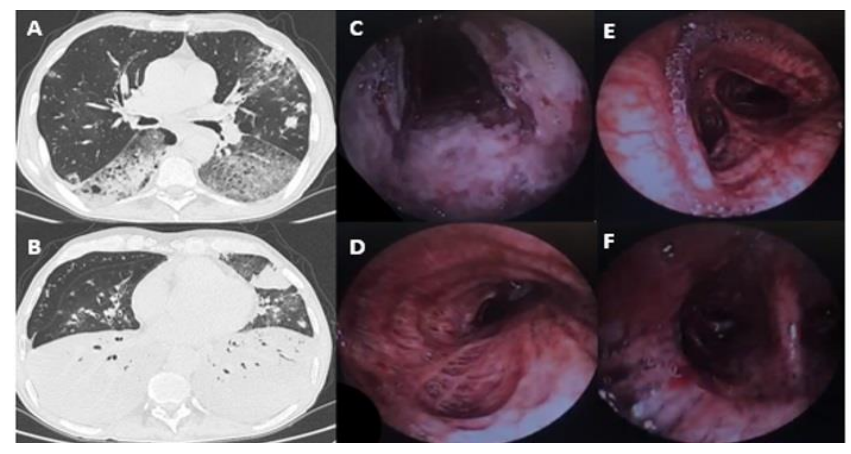

Figure 2: Bilateral ground-glass areas and opacity $(a, b)$, bronchoscopic findings: mucosal edema, hyperemia, hyperpigmentation, atrophy $(c, d, e, f)$

\section{DISCUSSION}

HFNO can deliver heated and humidified air-oxygen mixture inspired oxygen fraction $\left(\mathrm{FiO}_{2}\right)$ of between $21 \%$ and $100 \%$ and with a flow rate that can be increased up to $60 \mathrm{~L} / \mathrm{min}$. HFNO has important physiological effects in reducing the anatomical dead space and the positive end-expiratory pressure effect, and providing a constant fraction of inspired oxygen. HFNO is used in various conditions, such as hypoxemic respiratory failure, acute exacerbation of chronic obstructive pulmonary disease (COPD), post-intubation and pre-intubation, and for endstage patients. The incidence of hypoxic respiratory failure in COVID-19 pneumonia is uncertain, although approximately $14 \%$ of patients require oxygen support, and $5 \%$ need intensive care and mechanical ventilation $(1,4)$.

In a systematic review of three RCTs and 17 reviews, $\mathrm{HFNO}$ was found to reduce the need for intubation when compared to COT, while there was no difference in inhospital or intensive care mortality. In the same review, treatment-related complications linked to HFNO, thoraco-cervical discomfort, heat-related discomfort and mild consciousness levels were frequently observed (3). In a study conducted before the pandemic period, serious complications, including cardiac dysrhythmia, septic multiple cardiorespiratory arrest and nosocomial pneumonia were reported more frequently than COT with HFNO (5). $A$ review of literature revealed no information about the macroscopic effect of HFNO on the tracheobronchial system. Following a diagnosis of COVID-19 pneumonia in the intensive care unit, three patients underwent an early-period FOB after developing atelectasis, and similar lesions were observed in all parts of the tracheobronchial system, including mucosal hyperemia, hyperpigmentation, mucosal damage and oxygen burn-like lesions, and the mucosal structure was completely lost. No mucosal biopsy was taken in these patients because the procedures were performed through the intubation tube and under anticoagulant treatment, with high risk. In the absence of a pathological diagnosis, we believe that the damage was attributable to the HFNO, based on a macroscopic view, although the damage may also have developed due to ventilator-associated infections, primarily the COVID-19 infection, or microvascular damage. There is also no information about how this mucosal damage will progress in the future. In the future, secondary infections due to bronchial hyperplasia, granulation formation, deterioration of the ciliary structure, hemoptysis (due to bleeding diathesis) and malignancy developing on the scar formation may increase. The later complications associated with COVID-19 pneumonia and its treatment will become more apparent in time.

Studies are needed to evaluate how the flow rate and duration of HFNO therapy affect these clinical situations, although the most important hurdle is bronchoscopy, as if it is not indicated for a life-threatening situation in COVID-19, it can be considered too risky both for the medical staff and the patient. In the cases presented here, we performed the procedures with full personal protective equipment, in line with the recommendations of the American Association for Bronchology and Interventional Pulmonology (AABIP), since adequate oxygenation could not be provided by mechanical ventilation, and newlydeveloped atelectasis was observed from chest $X$-rays (6). In the editorial letter of Torrego et al. (7), it was stated that 93 patients under invasive mechanical ventilation in the intensive care unit during the COVID-19 period underwent bronchoscopy for many reasons, such as atelectasis, hemoptysis and for the obtaining of specimens, and ultimately localized mucosal hyperemia, white gelatinous secretions and crusts were observed. This article makes no mention of the widespread, damage to the mucosa seen in our patients, and there is also a lack of information on the use of HFNO prior to invasive mechanical ventilation in this patient group.

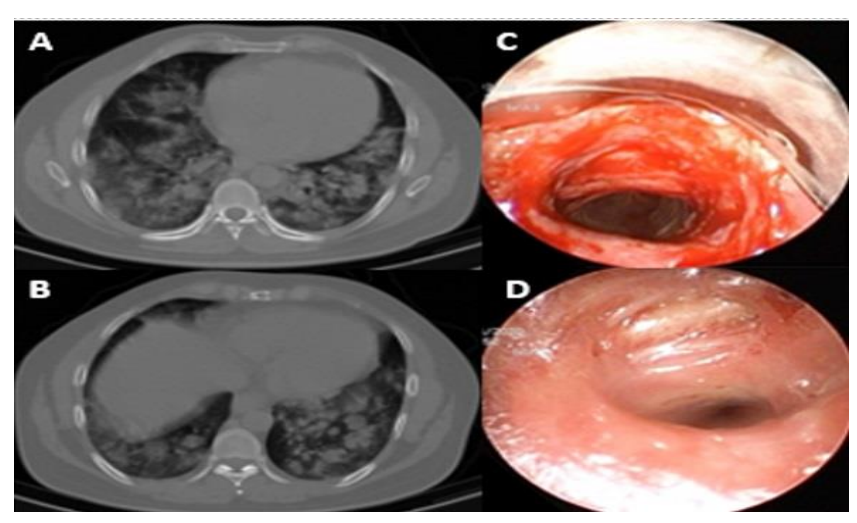


Figure 3: Bilateral ground-glass opacity $(a, b)$, mucosal edema, hyperemia $(c, d)$

The main limitation of the present study is the absence of a pathological diagnosis of the damage. Although there may be different etiologies, the similarity of the lesions strongly suggests that the damage may be due to HFNO. These mucosal findings have not been previously discussed in literature. HFNO is in wide use worldwide in patients who develop respiratory failure in COVID-19, although the long-term effects of this treatment remain unknown. When applying HFNO therapy, it is necessary to plan the duration of the treatment and the transition to other treatments, given the expected mucosal damage in the respiratory system. Patients may develop chronic cough, or apply as COPD in the long term, and the treatment they received during the COVID-19 period should be questioned in this respect.

\section{CONFLICTS OF INTEREST}

None declared.

\section{AUTHOR CONTRIBUTIONS}

Concept - M.U.Ş., S.A., A.Ö.; Planning and Design M.U.Ş., S.A., A.Ö.; Supervision - M.U.Ş., S.A., A.Ö.; Funding - M.U.S..; Materials - M.U.Ş., A.Ö.; Data Collection and/or Processing - M.U.S.., A.Ö.; Analysis and/or Interpretation - M.U.Ş., S.A., A.Ö.; Literature Review M.U.Ş., A.Ö.; Writing - M.U.Ş.; Critical Review - M.U.S.., A. Ö.

\section{YAZAR KATKILARI}

Fikir - M.U.Ş., S.A., A.Ö.; Tasarım ve Dizayn - M.U.Ş., S.A., A.Ö.; Denetleme - M.U.Ş., S.A., A.Ö.; Kaynaklar M.U.Ş.; Malzemeler - M.U.Ş., A.Ö.; Veri Toplama ve/veya İşleme - M.U.Ş., A.Ö.; Analiz ve/veya Yorum M.U.Ş., S.A., A.Ö.; Literatür Taraması - M.U.S.., A.Ö.; Yazıyı Yazan - M.U.Ş.; Eleştirel İnceleme - M.U.Ş., A.Ö.

\section{REFERENCES}

1. $\mathrm{Wu}_{\mathrm{Z}} \mathrm{Z}, \mathrm{McGoogan}$ JM. Characteristics of and important lessons from the coronavirus disease 2019 (COVID-19) outbreak in China: Summary of a report of 72314 cases from the Chinese Center for Disease Control and Prevention. JAMA2020; 323:1239-42. [CrossRef]

2. Delclaux C, L'Her E, Alberti C, Mancebo J, Abroug F, Conti $G$, et al. Treatment of acute hypoxemic nonhypercapnic respiratory insufficiency with continuous positive airway pressure delivered by a face mask: a randomized controlled trial. JAMA 2000; 284: 2352-60. [CrossRef]

3. Agarwal, A., Basmaii, J., Muttalib, F, Granton D, Chaudhuri $D$, Chetan $D$, et al. High-flow nasal cannula for acute hypoxemic respiratory failure in patients with COVID-19: systematic reviews of effectiveness and its risks of aerosolization, dispersion, and infection transmission. Can J Anaesth 2020; 67, 1217-48. [CrossRef]

4. Alhazzani W, Møller MH, Arabi YM, Loeb M, Gong MN, Fan E, et al. Surviving Sepsis Campaign: guidelines on the management of critically ill adults with Coronavirus Disease 2019 (COVID-19). Intensive Care Med 2020; 46:854-87. [CrossRef]

5. Frat JP, Thille AW, Mercat A, Girault C, Ragot S, Perbet S, et al. High-flow oxygen through nasal cannula in acute hypoxemic respiratory failure. N Engl J Med 2015; 372:2185-96. [CrossRef]

6. Wahidi MM, Lamb C, Murgu S, Musani A, Shojaee S, Sachdeva A, et al. American Association for Bronchology and Interventional Pulmonology (AABIP) Statement on the Use of Bronchoscopy and Respiratory Specimen Collection in Patients with Suspected or Confirmed COVID-19 Infection. J Bronchology Interv Pulmonol 2020; 27: e52e54. [CrossRef]

7. Torrego A, Pajares V, Fernández-Arias C, Vera P, Mancebo J. Bronchoscopy in patients with COVID-19 with invasive mechanical ventilation: a single-center experience. Am J Respir Crit Care Med 2020; 202:284-7. [CrossRef] 